\title{
Evaluation of performances of different types of spray nozzles in site-specific pesticide spraying
}

\section{Avaliação do desempenho de diferentes tipos de bicos de pulverização na pulverização de pesticidas em locais específicos}

\author{
Ali Bolat ${ }^{*}$; Ömer Baris Özlüoymak ${ }^{2}$
}

\section{Highlights:}

Site-specific and the broadcast spraying methods were compared by using three different nozzle types.

The spray distribution of the site-specific method in comparison with the reference (broadcast) method was investigated. Site-specific spraying applications did not cause any negative impact on depositions and coverage rates.

\begin{abstract}
In recent years, site-specific spraying methods, which are capable of combining the image processing technologies with electronic and information technologies, have been started to be used in the weed control and target-oriented spraying. In this study, in addition to the site-specific spraying in laboratory conditions; a mobile spraying system, which can also perform broadcast application as a reference method, was set up. The spraying performance of the mobile system was tested for three different nozzle types (standard flat fan nozzle, cone nozzle, air induction nozzle) and at speeds of $0.48,0.60,0.72$ and $0.84 \mathrm{~km} \mathrm{~h}^{-1}$. The mobile system was operated as both broadcast and site-specific for each nozzle type and travel speed. Three artificial weed samples were used at $75 \mathrm{~cm}$ intervals as sampling surfaces on the movement of the mobile system in the spraying operations; filter papers (FP) and water-sensitive papers (WSP) were placed behind them on the bars. While deposition values were measured with the filter papers, water-sensitive papers were used to measure the coverage rates. The spray distribution of the site-specific method in comparison with the reference method was investigated. According to the results, site-specific spraying applications did not cause any negative impact on depositions and coverage rates. The nearest results compared with the broadcast spraying were obtained with the air induction nozzle type at a speed of $0.48 \mathrm{~km} \mathrm{~h}^{-1}$ with a $60.5 \%$ deposition amount and $95.9 \%$ coverage rate.
\end{abstract}

Key words: Air induction nozzle. Broadcast spraying. Cone nozzle. Flat fan nozzle. Site-specific spraying.

\section{Resumo}

Nos últimos anos, começaram a ser utilizados métodos de pulverização específicos do local, capazes de combinar as tecnologias de processamento de imagem com as tecnologias eletrônicas e de informação, no controle de ervas daninhas e na pulverização orientada para o alvo. Neste estudo, além da pulverização específica do local em condições de laboratório; foi instalado um sistema de pulverização móvel, que também pode executar a aplicação de transmissão como método de referência. $\mathrm{O}$ desempenho de

${ }^{1} \mathrm{PhD}$, Eastern Mediterranean Agricultural Research Institute, Republic of Turkey Ministry of Agriculture and Forestry, Adana, Turkey. E-mail: bolat.ali@tarimorman.gov.tr

2 Assist. Prof. Dr., Çukurova University, Faculty of Agriculture, Department of Agricultural Machinery and Technologies Engineering, Adana, Turkey. E-mail: ozluoymak@cu.edu.tr

* Author for correspondence 
pulverização do sistema móvel foi testado para três tipos diferentes de bicos (bico de ventilador plano padrão, bico de cone, bico de indução de ar) e nas velocidades de $0,48,0,60,0,72 \mathrm{e} 0,84 \mathrm{~km} \mathrm{~h}^{-1}$. O sistema móvel foi operado como broadcast e específico do local para cada tipo de bico e velocidade de deslocamento. Três amostras de plantas daninhas artificiais foram usadas em intervalos de $75 \mathrm{~cm}$ como superfícies de amostragem no movimento do sistema móvel nas operações de pulverização; papéis de filtro (FP) e papéis sensíveis à água (WSP) foram colocados atrás deles nas barras. Enquanto os valores de deposição foram medidos com os papéis de filtro, papéis sensíveis à água foram usados para medir as taxas de cobertura. A distribuição de spray do método específico do local em comparação com o método de referência foi investigada. De acordo com os resultados, as aplicações de pulverização específicas do local não causaram impacto negativo nos depoimentos e nas taxas de cobertura. Os resultados mais próximos comparados com a pulverização por difusão foram obtidos com o tipo de bico de indução de ar a uma velocidade de $0,48 \mathrm{~km}$ h-1 com uma quantidade de deposição de $60,5 \%$ e taxa de cobertura de $95,9 \%$.

Palavras-chave: Bocal de indução de ar. Pulverização de transmissão. Bico em cone. Bocal de ventilador plano. Pulverização específica do local.

\section{Introduction}

Weeds cause significant harm in agricultural production and damage the product during the development phase of the crop plant. In addition, weeds serve as a host for insects and creatures with many disease agents that are harmful to crop plants. Sustainable farming can be described as a production method which considers environmental factors such as air and water by conserving human, plant and animal health (Baran, Polat, \& Gökdoğan, 2016). Chemical weed control is made with pesticides known as herbicides and this method reduces the product losses. Typically recommended for the weed control are standard flat fan nozzles. Although these nozzle types provide a good weed control in controlled laboratory conditions, it is stated that it has high drift rates in field conditions and cannot achieve high success rate (Soysal \& Bayat, 2006). Nowadays, it is not possible to completely eliminate the herbicide drift in current spraying applications. However, in recent years, air induction nozzles with low drift potential which have been increasingly used in weed spraying, have been developed. Air induction nozzles and the holes on the nozzle body allow air to enter. Thus, droplets of larger diameters with air induction nozzles are produced, drift is reduced, penetration increases and high coverage can be achieved on the target area (Bolat et al., 2018; Doruchowski et al., 2017).
Nowadays, herbicide spraying is done in the form of broadcast spraying of the entire field surface; this is the most conventionally known method. In sprayings done by this method; high amounts of herbicides are used to spraying the entire field surface, so soil, environment and water sources are heavily contaminated. High application volume and excessive use of herbicides arise the result of the resistance of weeds and the deterioration of natural equilibrium. In recent years, for the reduction of this problem, the selection of weeds and the sitespecific spraying have taken place as an important strategy (Tang, Chen, Miao, \& Wang, 2016). In sitespecific sprayings, instead of broadcast spraying in which all field surface is sprayed, target-oriented sprayings which make decisions with algorithms formed by image processing has begun (Tian, Reid, \& Hummel, 1999). While the liquid spraying from the nozzles during the spraying is carried out continuously and with the same flow from all nozzles in the conventional method, in site-specific spraying, the spraying is targeted only to the point where the weed is located. In site-specific spraying, the weed density is calculated by using image processing algorithm according to the greenness method and then, the target weed spraying is provided (Özlüoymak, Bolat, Bayat, \& Güzel, 2019; Shirzadifar, Loghavi, \& Raoufat, 2015), in their study, compared site-specific and broadcast 
spraying methods (at the speeds of $0.42,0.54,0.66$, 0.78 , and $0.90 \mathrm{~km} \mathrm{~h}^{-1}$ ), and they achieved spraying saving rates of up to $89.48 \%$ by site-specific method. Christensen et al. (2009) used spray nozzles acting on the solenoid valves in the electronic system for herbicide application and the system successfully detected weed and formed a successful image processing algorithm. Yang, Prasher, Landry and Ramaswamy (2002), in their study carried out in a field of corn plant cultivation, have identified the objects in the digital image with the image processing algorithm. They have developed and provided high success rates in spraying. Martín, Andújar, Barroso, Fernández-Quintanilla and Dorado (2016) showed a success rate of up to $66 \%$ in sparse weed species while achieving a success of up to $20 \%$ in heavily dispersed weed species. Shirzadifar et al. (2015), has provided $75 \%$ less herbicide consumption with the use of site-specific spraying method with realtime imaging method in their herbicide applications when compared to the conventional method. Perez, Lopez, Benlloc and Christensen (2000), in their research, in the determination of weeds in crop fields, used image processing technique which can make shape and colour analysis and stated that the method has very high accuracy.

Sabanc1 and Aydın (2014) identified weeds in the sugar beet fields using image processing techniques, and with the precision spraying robot developed during the study. Variable rate herbicide application was measured at 8 different speeds and they achieved a saving of $55.22 \%$ compared to the conventional method. Among the nozzle types commonly used in sprayers are flat fan and cone nozzles. However, in recent years, manufacturers have produced air induction nozzles that can increase the efficiency of collecting herbicides at the target, and reduce drift, to improve herbicide application technologies. In case of use of these nozzle types applied by the conventional methods in site-specific spraying, the possible success rate and the spray pattern distributions is not yet known.

The aim of this study is determination of deposition and coverage rates obtained at different nozzle types and speeds by site-specific and broadcast spraying methods.

\section{Material and Methods}

\section{Material}

The research was carried out in the spraying laboratory in the Department of Agricultural Machinery and Technologies Engineering, Faculty of Agriculture, Çukurova University, Adana, Turkey. In the study, an electric motor powered mobile spraying system was designed. System was tested at 4 different speeds $(0.48,0.60,0.72$ and $\left.0.84 \mathrm{~km} \mathrm{~h}^{-1}\right)$ and with three different nozzle types(1Standard flat fan nozzle, (STFF 8002 / Lechler Co.), 2-Conenozzle (CN 8002 / Lechler Co.), 3- Air induction nozzle (AIN 11002 / Lechler Co.)).

In addition to site-specific spraying ( $\mathrm{Ss}$ ), mobile system also has the ability to perform broadcast spraying (Brd). For the types of nozzles used in the research, broadcast spraying applications were carried out at each travel speed.

The flow rates at the different speeds of each nozzle used in the study, along the movement path of the mobile system $(400 \mathrm{~cm})$ generated by the application in the form of a broadcast method are given in Table 1. 
Table 1

Flow rates of nozzle types used in the study by broadcast spraying

\begin{tabular}{ccccc}
\hline \multirow{2}{*}{$\begin{array}{c}\text { Speed } \\
\left(\mathrm{km} \mathrm{h}^{-1}\right)\end{array}$} & $\begin{array}{c}\text { Pressure } \\
(\mathrm{kPa})\end{array}$ & FF & Flow rate $\left(\mathrm{ml} 400 \mathrm{~cm}^{-1}\right)$ \\
\cline { 3 - 5 } & 200 & 325 & 335 & $\mathrm{CN}$ \\
\hline 0.48 & 200 & 270 & 275 & 335 \\
0.60 & 200 & 230 & 230 & 280 \\
0.72 & 200 & 200 & 200 & 240 \\
0.84 & & & & 210 \\
\hline
\end{tabular}

In addition to the electronic unit on the mobile system, the solenoid valve (Torque, S101003145N) and spraying nozzle connecting head parts were also included. For image acquisition, a web camera was used in the system (Logitech C270). In addition, a data acquisition card (National Instruments Corporation, Austin-Texas-USA, NI USB-6009) and a $12 \mathrm{~V} 16$-channel relay card were used to collect environmental data (speed information, etc.) and to operate the solenoid valve. The system moved on the rails with the help of a $0.37 \mathrm{~kW}$ electric motor (WAT, QS71M4B) coupled to the reducer. The mobile system could move forward and backward on a $400 \mathrm{~cm}$ long rail system. Direction change was also provided by optical sensors (Pepperl+Fuchs, GLV18-8-450/115/120) which saw plates placed at both ends of the rails. The speed and direction of movement of the mobile system could be set by the variable frequency controller (ABB micro drives, ACS355) and the speed information for the robot was provided by the inductive proximity sensor (Sick, IME08-04NPSZW2S) which counted a magnetic part on the motor shaft. The speed of the vehicle was also checked by a tachometer (Prova, RM-1500) to determine whether it was correct or not. The energy of the sensors and electronic cards on the system was provided by a DC power supply (Pacific, 2305D+). Software for image processing and automation of the mobile system was carried out using a laptop computer (Acer, Aspire E15) in LabVIEW (National Instruments Corporation, Austin-Texas-USA) programming language. The image of the mobile system is shown in Figure 1.

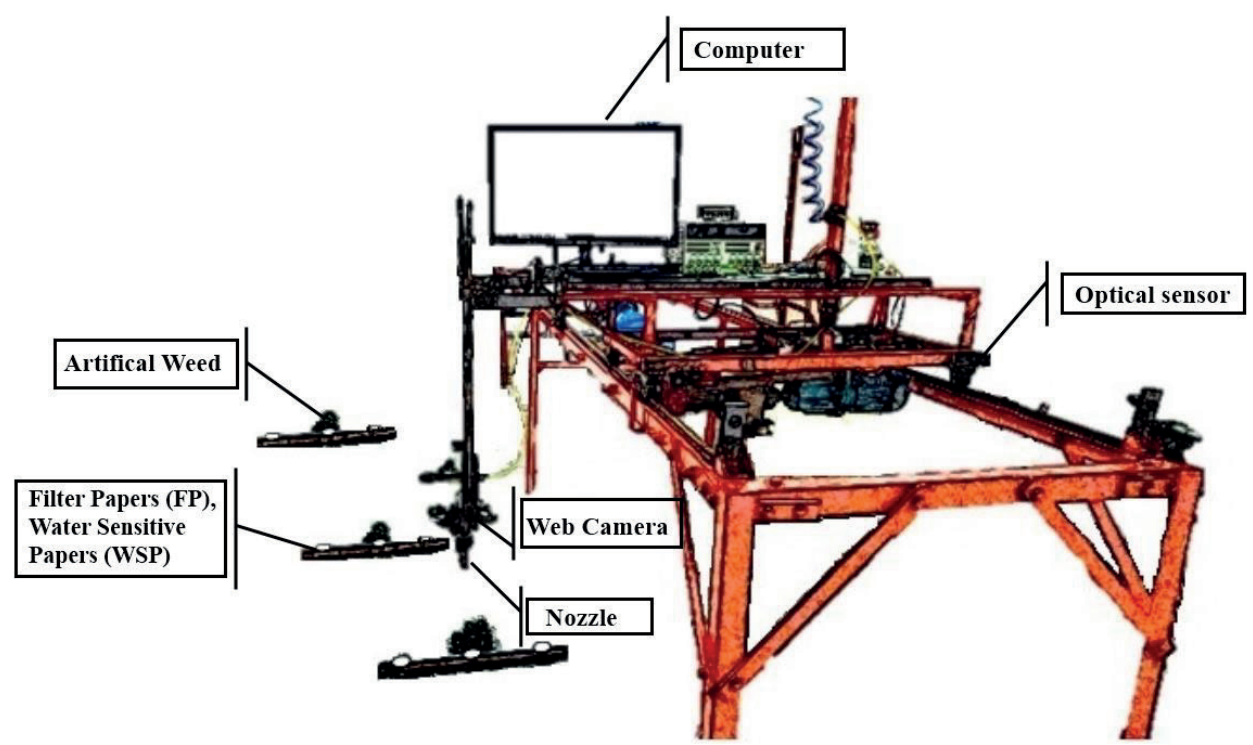

Figure 1. Schematic view of mobile spraying unit. 
The liquid flow to the nozzle in the spraying unite of the mobile system was provided by a pressurized pre-mix tank operated by the compressor. Air was compressed into the tank by means of the compressor. The spray pressure was read in the manometer after setting with a pressure regulator (STNC, TC 2010-02), and all applications were made at a constant pressure of $200 \mathrm{kPa}$. The dynamic mechanism to which the spraying unit was connected had a nozzle that could be removed and attached, a solenoid valve activating the nozzles. The image was taken with a web camera mounted just in front of the nozzle, and the spraying decision was operated by processing the image.

Deposition amount and coverage rate measurements were made for each nozzle type and travel speed. To determine the amount of deposits, BSF (Brillant Sulpho Flavin), filter papers (Schleicher\&Schuell, Whatman, Ø25mm), shaker device (Nüve, SL 350) and spectrofluorophotometer (Shimadzu, RF-6000) were used. Water sensitive papers (Syngenta, $26 \times 76 \mathrm{~mm}$ ) were used to determine the coverage rates. Droplets on watersensitive papers was scanned at 600 dpi (600 pixels / $25.4 \mathrm{~mm}$ ) in a scanner for measurement of coverage areas and analysed with an improved image processing software (NI Vision Builder for Automated Inspection, National Instruments Corporation, Austin-Texas-USA).

\section{Method}

The working principle of the Site-specific (Ss) spraying system

With broadcast spraying applications, the entire field surface was sprayed continuously. However, in the site-specific spraying method, only weeds were sprayed depending on the perception of the camera. For this purpose, a mobile spraying system was developed with the software developed using the LabVIEW programming language. Images acquired by the camera connected to the mobile system were transferred to a laptop computer and only the artificial weeds, which were perceived as green were sprayed.

Greenness method in which there, green, and blue intensities of each pixel were compared, was used to determine the weed coverage. It was applied to highlight the green colour information after capturing RGB image and separating its components. The artificial weed could be determined by selecting a threshold value as shown in Figure 2.
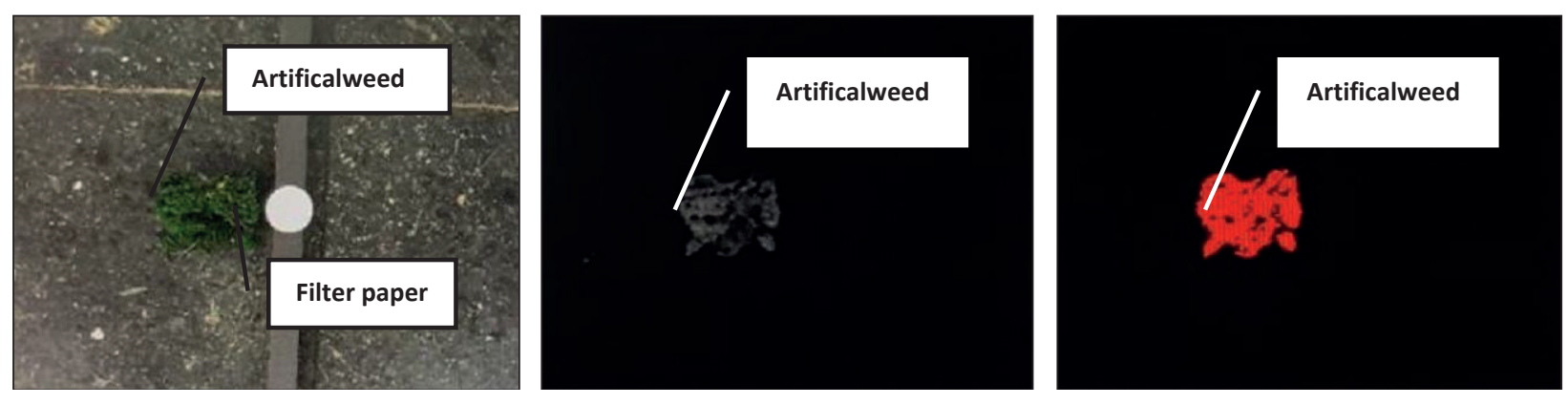

Figure 2. Artificial weed tracking application.

Equation 1 was used based on the algorithm of the selection of green objects and the image was separated to RGB channels in the system decision (Loni, Loghavi, \& Jafari, 2014).

$$
\mathrm{EXG}=2 \mathrm{G}-\mathrm{R}-\mathrm{B}
$$

In the equation;

EXG: Excessive green,

R: Red,

G: Green and

B: Blue 
When broadcast spraying was applied, the sitespecific system was disabled and the spraying of the nozzle along the rail system $(400 \mathrm{~cm})$ was enabled.

\section{Determination of deposition amount}

Water and BSF (Brillant Sulpho Flavin) trace material $\left(0.4 \mathrm{~g} \mathrm{l}^{-1}\right)$ were used as spray liquid. In the deposit measurements, 3 artificial weeds at 75 $\mathrm{cm}$ intervals and 7 filter papers on the metal bars were located to the ground (Figure 3). Filter papers were placed on the metal bar at intervals of $5 \mathrm{~cm}$ $(-15 ;-10 ;-5 ; 0 ;+5 ;+10 ;+15)$ to determine the liquid distribution. Thus, liquid distributions were determined by each method. In addition, a total of 21 deposit amounts of filter paper were determined for each spraying. Each method was applied with 3 replications.

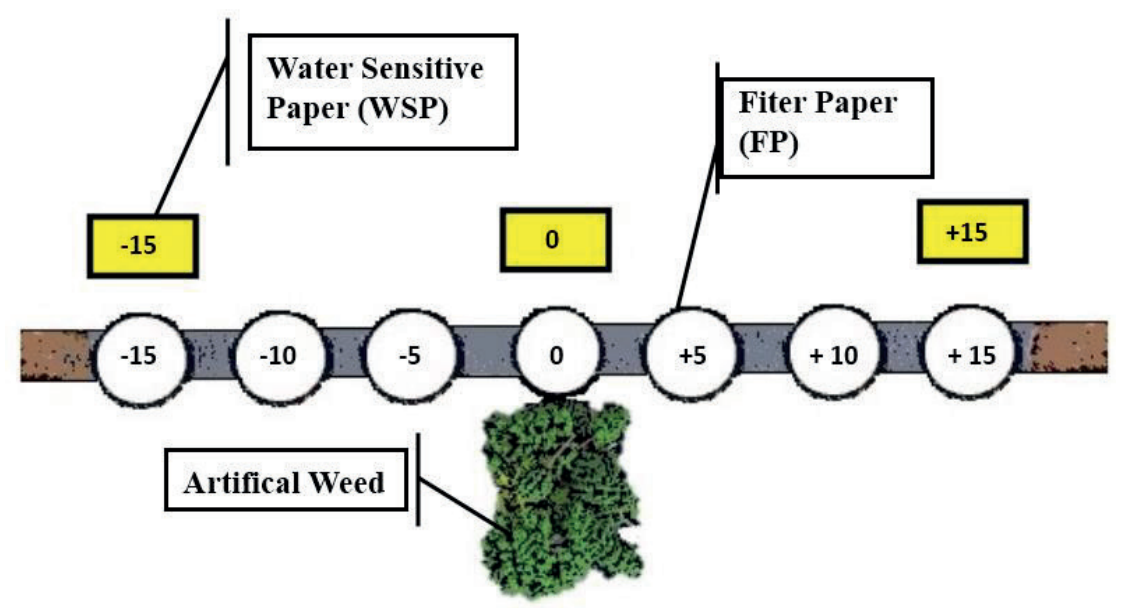

Figure 3. Schematic view of the sampling apparatus.

The filter papers were collected on numerically encoded glass jars to determine the spray deposits. $20 \mathrm{ml}$ of distilled water was added to each glass jar and agitated for 10 minutes in the shaker device. The liquid samples from the jars were analysed by spectrofluorophotometer and the deposit amount of each sample was determined. The fluorometric readings were converted to the real concentration values by using the following calibration Equation 2 .

$$
\begin{aligned}
& y=2131.21 x+180.052 \\
& r^{2}=0.99793
\end{aligned}
$$

In the equation;

y: Referred to the intensity

$\mathrm{x}$ : Referred to the concentration values,

$r^{2}$ : Referred the coefficient of determination

The formula given in Equation 3 was used to convert the measured values to $\mu \mathrm{g} \mathrm{cm}^{-2}$ (Bolat, 2010).

$$
\mathrm{f}_{\mathrm{x}}=\mathrm{m} \cdot \mathrm{V}_{\mathrm{L}} \cdot 1 / \mathrm{A}
$$

In the equation;

$\mathrm{f}_{\mathrm{x}}$ : Fluorometric coefficient dependent on degree of precision $\left(\mu \mathrm{g} \mathrm{cm}^{-2}\right)$

$\mathrm{m}$ : Concentration factor $\left(\mathrm{mgml}^{-1}\right)$

$\mathrm{V}_{\mathrm{L}}$ : The amount of pure water used to wash the trace substance on the filter paper $(\mathrm{ml})$

A: Trace material collection surface area $\left(\mathrm{cm}^{2}\right)$

\section{Determination of coverage rates}

3 water-sensitive papers (WSP) (Figure 3) were positioned directly behind the 3 artificial weeds located on the spraying path of the mobile system. 
One of the water-sensitive papers was placed in the sampling centre and the other two were placed on the outer edges $(-15 ; 0 ;+15)$ and a total of 9 WSP measurements ( 3 artificial weeds $\mathrm{x} 3$ water-sensitive papers) were carried out along the motion path. The measurements conducted on the mobile system were applied 3 times for each nozzle type and travelling speed. Water-sensitive papers scanned after spraying and converted to JPEG format were analysed with software developed in the NI Vision Builder for Automated Inspection image processing program. Thus, the coverage rate for each watersensitive paper was obtained with the analysis program (Figure 4).

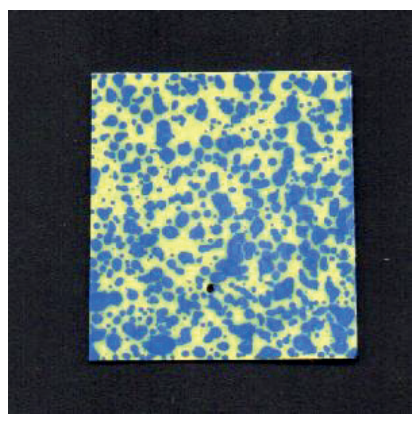

Original Image

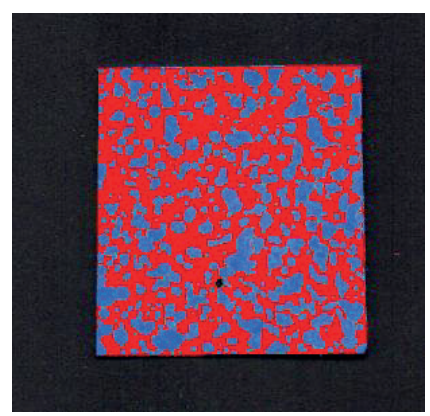

Pixel Counting

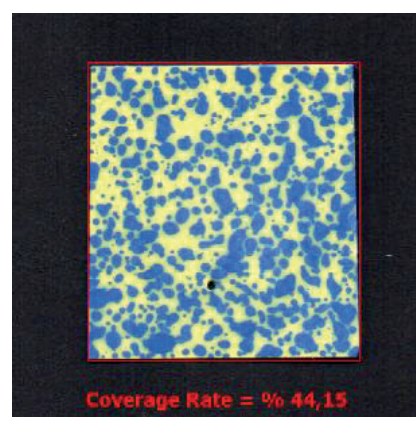

Coverage Rate

Figure 4. Image processing steps of water-sensitive papers.

Areas that changed from yellow to blue on water-sensitive papers indicate the coverage areas. The coverage area was calculated by subtracting blue coloured pixels from the yellow ones with developed software.

To make a sense of droplet uniformity of spray, characteristics droplet diameters such as $\mathrm{Dv}_{0.1}, \mathrm{Dv}_{0.5}$ and $\mathrm{Dv}_{0.9}$ of nozzles were measured in the Lab conditions by using a laser measurement device (Malvern Spraytec-Open Spray).

Droplet size distributions were determined in the same pressure $(200 \mathrm{kPa})$ during 60 second periods for each nozzle type. Relative span (R) was determined for homogeneity coefficients of droplet sizes of each nozzle by using the following equation (Equation 4).

$$
\mathrm{R}=\mathrm{Dv}_{0.9}-\mathrm{Dv}_{0.1} / \mathrm{Dv}_{0.5}
$$

In the equation;

R: Relative span;

$\mathrm{Dv}_{0.9}: 90$ percent of spray volume is in droplet size smaller than this value;

$\mathrm{Dv}_{0.1}: 10$ percent of spray volume is in droplets size smaller than this value;

$\mathrm{Dv}_{0.5}:$ Volume median diameter ( $\% 50$ of the volume).

\section{Results}

\section{Deposition amounts}

In the study; Table 2 shows the results of total deposition amounts obtained by both site-specific and broadcast spraying applications in different nozzle types and speeds. 
Table 2

Deposit amounts for different nozzle types and different application volume $\left(\mu \mathrm{g} \mathrm{cm}^{-2}\right)$

\begin{tabular}{cccccccccc}
\hline \multirow{2}{*}{$\begin{array}{c}\text { Speed } \\
\left(\mathrm{km} \mathrm{h}^{-1}\right)\end{array}$} & \multicolumn{9}{c}{ Total Deposition $\left(\mu \mathrm{g} \mathrm{cm}^{-2}\right)$} \\
\cline { 2 - 10 } & Brd* & Ss** & Ss/Brd (\%) & Brd & Ss & Ss/Brd (\%) & Brd & Ss & Ss/Brd (\%) \\
\hline 0.48 & 0.0891 & 0.0472 & 52.9 & 0.0734 & 0.0351 & 47.9 & 0.074 & 0.044 & 60.5 \\
0.60 & 0.0685 & 0.0231 & 47.9 & 0.0632 & 0.0205 & 32.4 & 0.061 & 0.034 & 55.8 \\
0.72 & 0.0553 & 0.0140 & 25.3 & 0.0538 & 0.0162 & 30.1 & 0.041 & 0.020 & 49.8 \\
0.84 & 0.0413 & 0.0099 & 23.9 & 0.0334 & 0.0084 & 25.1 & 0.033 & 0.014 & 41.9 \\
\hline
\end{tabular}

*Broadcast (Brd) spraying was the reference for comparison

**Ss: Sit specific spraying application.

In all of the nozzle types used in the study, the nearest results to the reference method were obtained at the speed of $0.48 \mathrm{~km} \mathrm{~h}^{-1}$, while there was a decrease in these rates with the increase in the speed. For example, as can be seen in Table 2; the nearest value to the reference was obtained at 0.48 $\mathrm{km} \mathrm{h}^{-1}$ as $60.5 \%$ for the air induction nozzle type (AI). Similar to all nozzle types used in the study, with the increase in the speed value, results were closer to the reference value.

Spray deposition amounts at different spraying speeds for each nozzle type were given in Figures 5-7, respectively. As seen in Figures 5-7; the spray distributions of all nozzle types were similar to the broadcast spraying which was the reference method. In the sampling filter paper surfaces; high deposition amounts were determined in the samples located in the nozzle centres and these amounts decreased to the edges. However, due to the increase in speed, decreases in deposition amounts measured in both broadcast and site-specific methods were observed. As air induction nozzle (AI) produced larger drops and had a low tendency to drift, the amount of deposits measured at the edges was higher than the other nozzle types. In FF nozzle type, the results were close to the reference value at the lowest speed $\left(0.48 \mathrm{~km} \mathrm{~h}^{-1}\right)$ and spray distributions reaching to the edges due to speed increase significantly reduced. Similarly, while the cone nozzle $(\mathrm{CN})$ showed decreases in the amount of deposits due to the increase in speed, it can be said that the spray distribution that occurred when the travel speed increased, formed higher deposition amount compared to the flat fan (FF) nozzle.

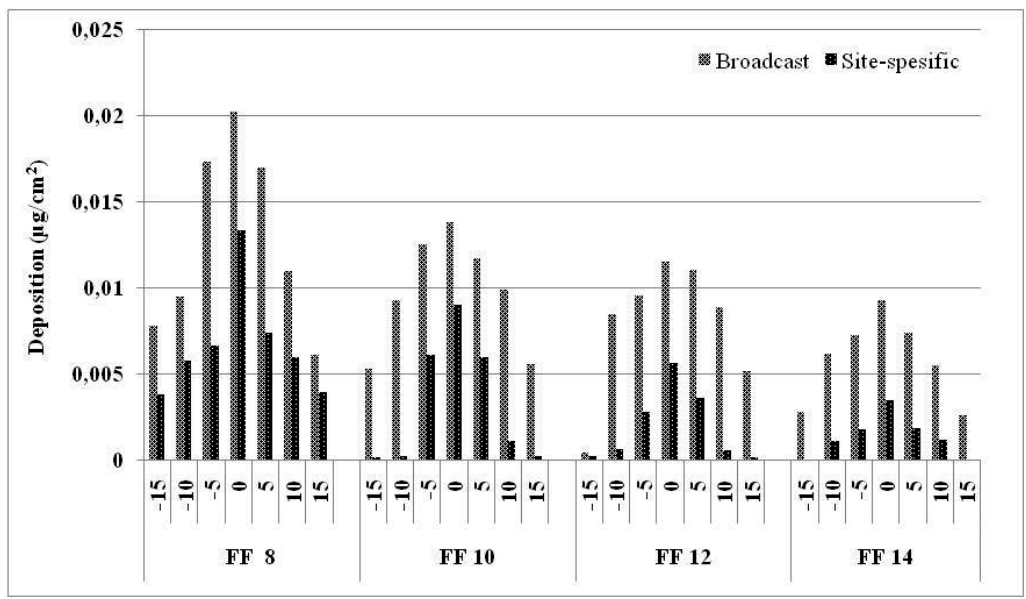

Figure 5. Spray distributions in terms of the deposition amount of the FF nozzle at different speeds. 


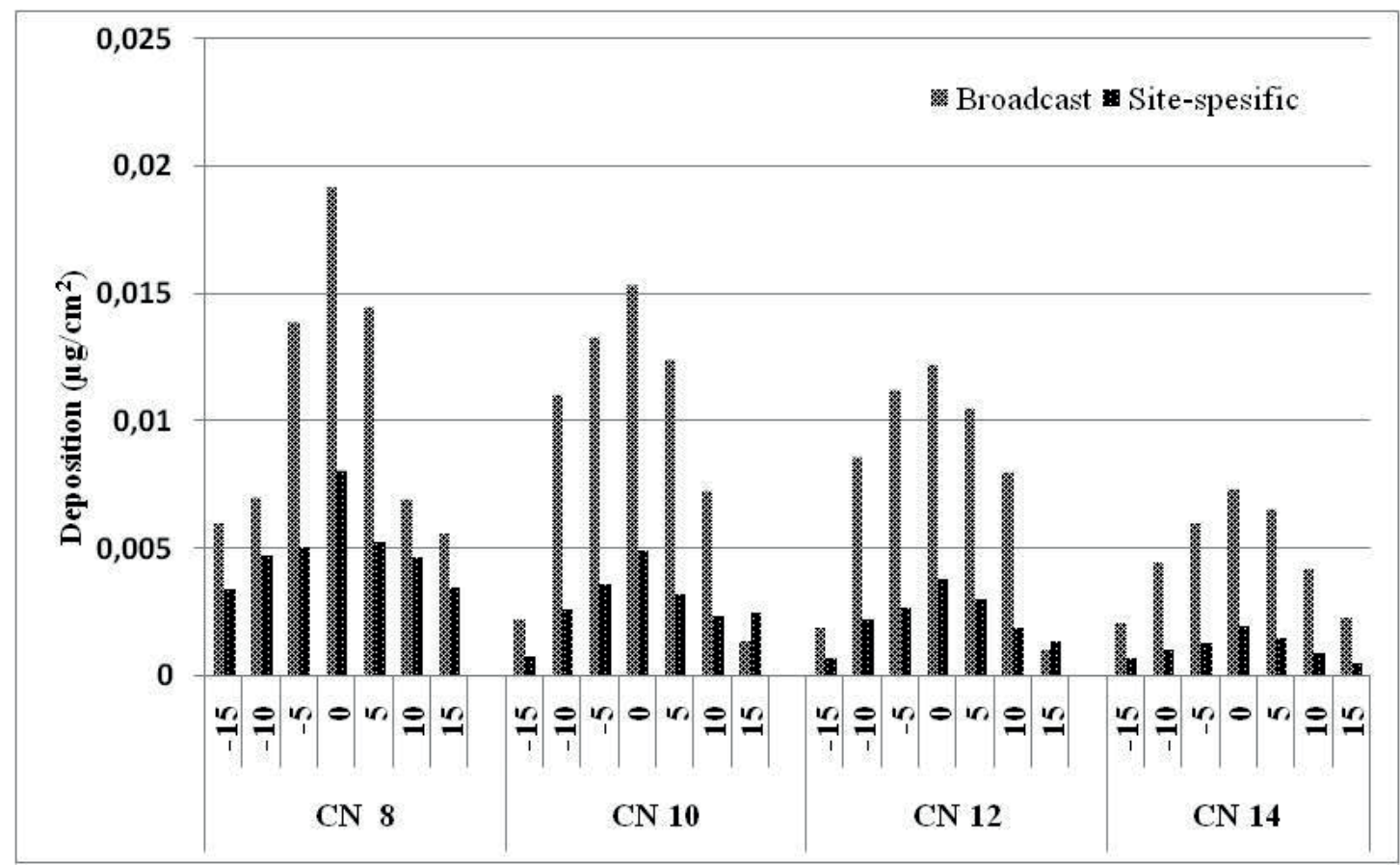

Figure 6. Spray distributions in terms of the deposition amount of the CN nozzle at different speeds.

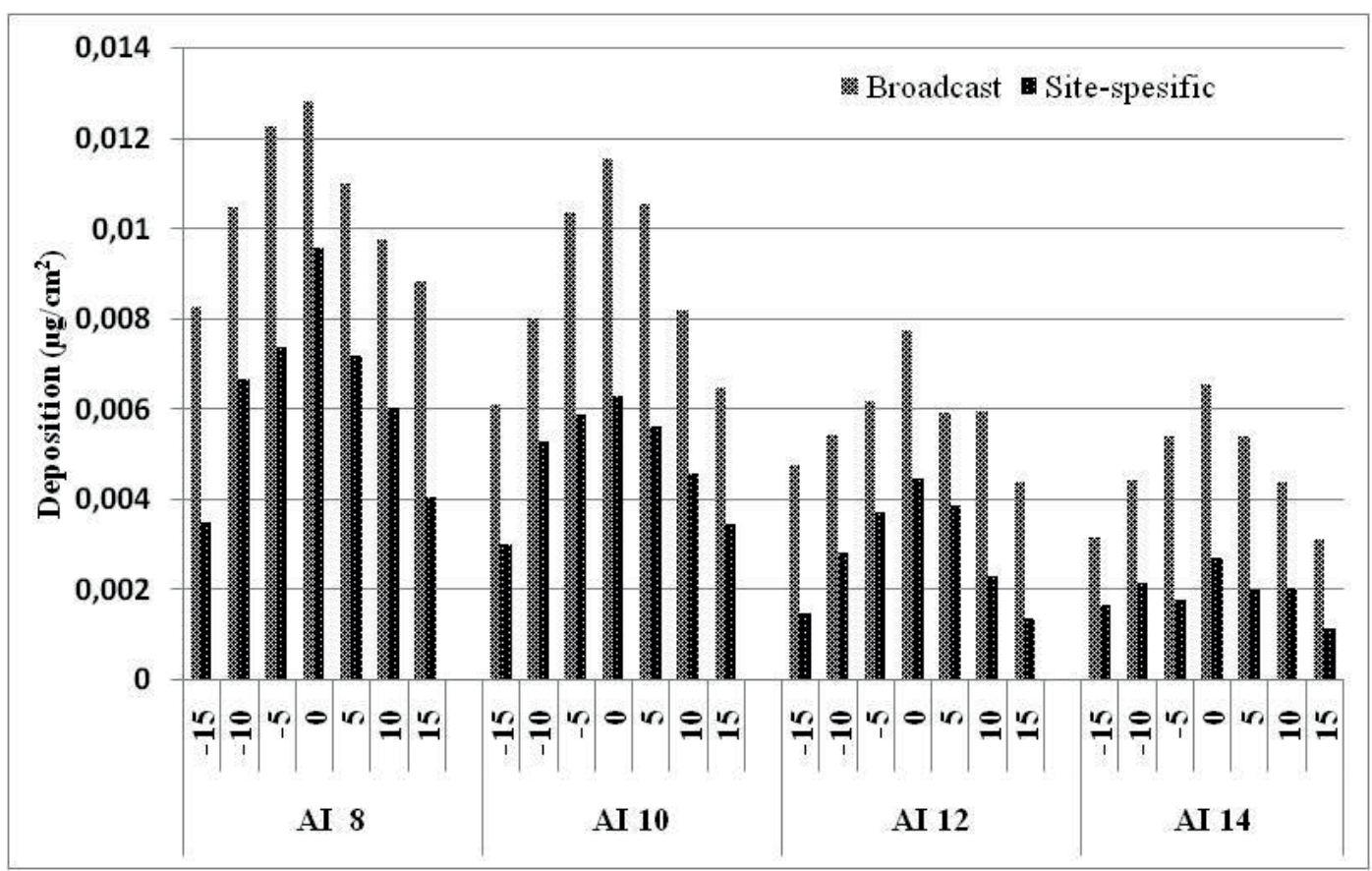

Figure 7. Spray distributions in terms of the deposition amount of the AI nozzle at different speeds.

\section{Coverage rate}

Table 3 presents the results of total coverage rates obtained by site-specific and broadcast spraying applications at different speeds and nozzle types. 
Table 3

Coverage rates at different speeds and different nozzle types (\%)

\begin{tabular}{cccccccccc}
\hline \multirow{2}{*}{$\begin{array}{c}\text { Speed } \\
\left(\mathrm{km} \mathrm{h}^{-1}\right)\end{array}$} & \multicolumn{9}{c}{ Total Coverage Rate (\%) } \\
\cline { 2 - 11 } & Brd & Ss & Ss/Brd (\%) & Brd & Ss & Ss/Brd (\%) & Brd & Ss & Ss/Brd (\%) \\
\hline 0.48 & 81.8 & 76.7 & 93.8 & 72.6 & 64.2 & 88.5 & 91.1 & 87.4 & 95.9 \\
0.60 & 78.9 & 68.9 & 87.3 & 63.3 & 52.9 & 83.6 & 88.8 & 83.1 & 93.6 \\
0.72 & 71.1 & 60.6 & 85.2 & 57.8 & 46.4 & 80.3 & 77.2 & 65.6 & 85.0 \\
0.84 & 57.1 & 47.5 & 83.2 & 58.6 & 43.8 & 74.8 & 75.1 & 60.7 & 80.9 \\
\hline
\end{tabular}

*Broadcast (Brd) spraying was the reference for comparison

**Ss: Sit specific spraying.

In terms of coverage rates, the ratio of Ss / Brd (\%) refers to the proximity ratio of site-specific application to the broadcast spraying method in Table 3. As the speed increased in all of the nozzle types used in the study, the coverage rates decreased. The closest coverage rate to the reference method was obtained with air induction (AI) nozzle type with a value of $95.9 \%$ and at a speed of $0.48 \mathrm{~km}$ $\mathrm{h}^{-1}$. According to the reference value, the furthest coverage rate was achieved with cone nozzle $(\mathrm{CN})$ with a rate of $74.8 \%$ and at a speed of $0.84 \mathrm{~km} \mathrm{~h}^{-1}$.

Spray distributions of each nozzle type according to the spraying speeds are shown in Figures 8-10, respectively. According to the results obtained from the figures, the broadcast spraying method in all of the nozzle types showed higher coverage rates than the site-specific method. Due to the increase in the speed, there was a decrease in the values of the coverage rates measured on the sampling surfaces.

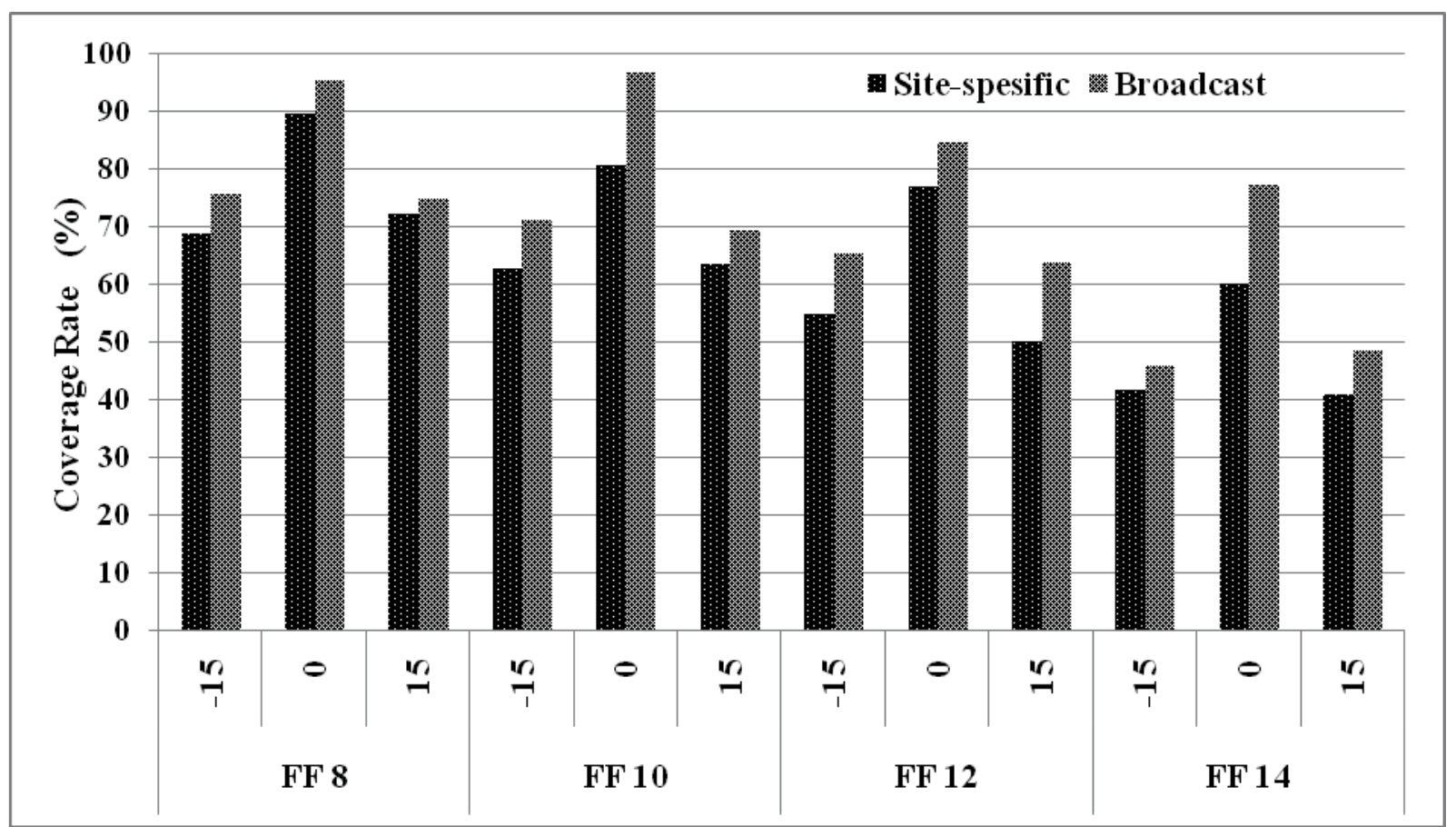

Figure 8. Spray distributions in terms of the coverage rate of the FF nozzle at different speeds 


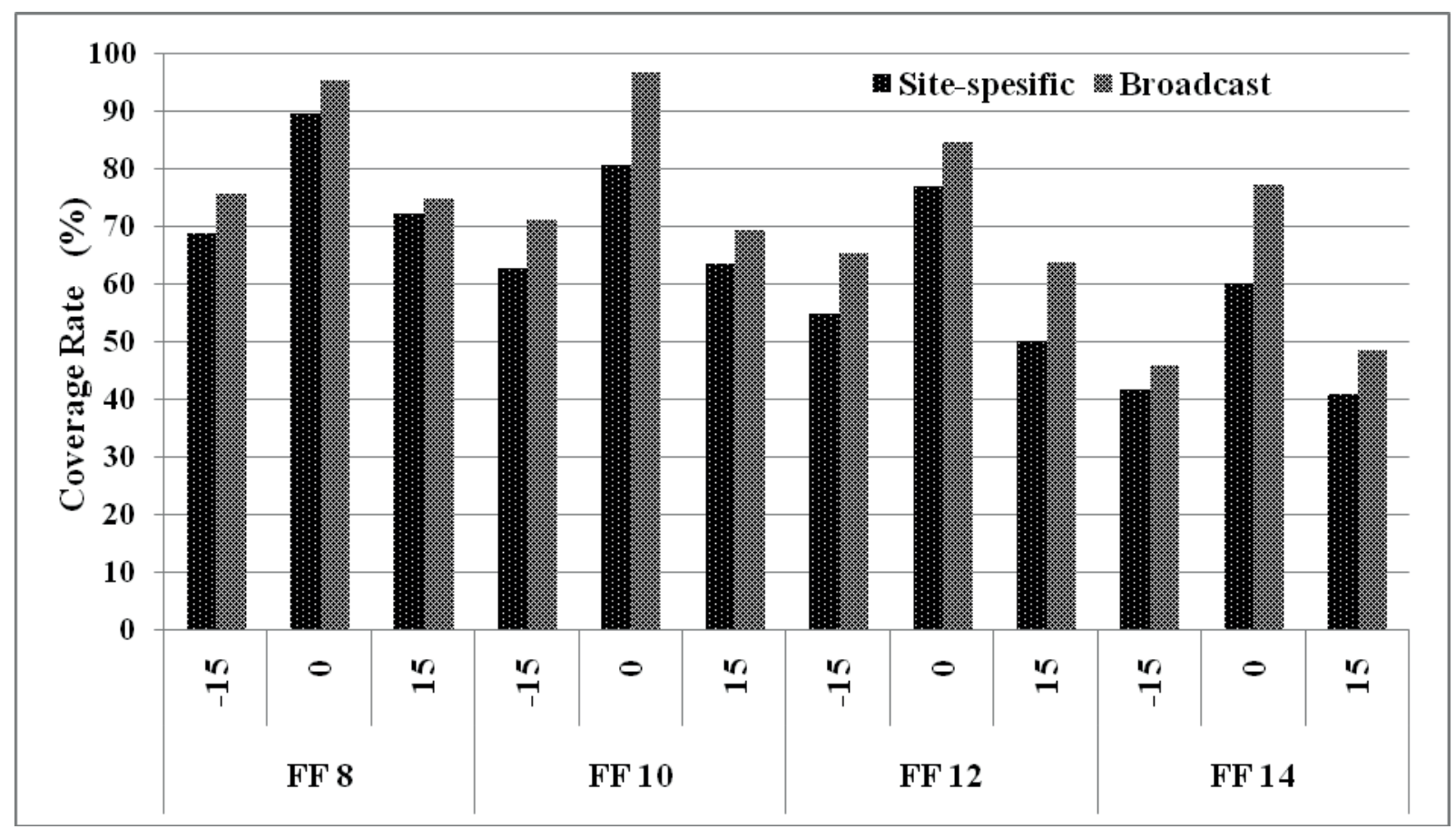

Figure 9. Spray distributions in terms of the coverage rate of the $\mathrm{CN}$ nozzle at different speeds

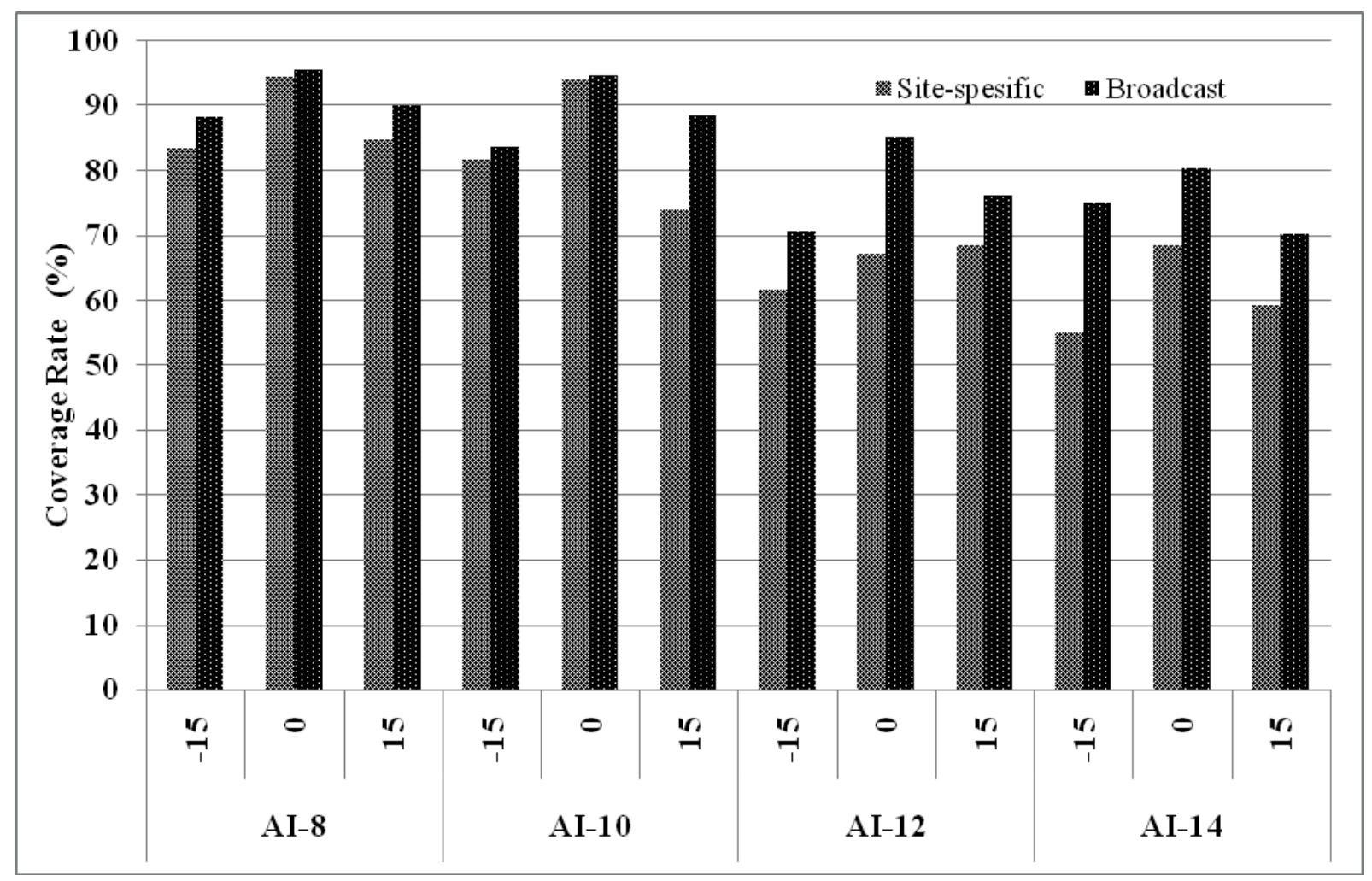

Figure 10. Spray distributions in terms of the coverage rate of the AI nozzle at different speeds 
The measurements and calculations of droplet

size characteristics are given in Table 4.

Table 4

Droplet size distribution for each method

\begin{tabular}{cccccc}
\hline Methods & $\begin{array}{c}\text { Pressure } \\
(\mathrm{kPa})\end{array}$ & $\begin{array}{c}\mathrm{Dv}_{0,1} \\
(\mu \mathrm{m})\end{array}$ & $\begin{array}{c}\mathrm{Dv}_{0,5} \\
(\mu \mathrm{m})\end{array}$ & $\begin{array}{c}\mathrm{Dv}_{0,9} \\
(\mu \mathrm{m})\end{array}$ & $\begin{array}{c}\text { Relative Span } \\
(\mathrm{R})\end{array}$ \\
\hline $\mathrm{FF}$ & 200 & 85.25 & 167 & 316 & 1.382 \\
$\mathrm{CN}$ & 200 & 62.69 & 127.7 & 223.1 & 1.201 \\
$\mathrm{AI}$ & 200 & 139.2 & 357.6 & 702.5 & 1.575 \\
\hline
\end{tabular}

As shown in the Table 4, the highest $\mathrm{Dv}_{0.5}$ was obtained from air induction (AI) nozzle at 357.6 $\mu \mathrm{m}$ and the lowest $\mathrm{Dv}_{0,5}$ was obtained from cone nozzle $(\mathrm{CN})$ at $127.7 \mu \mathrm{m}$. Proximity of "R value" to 1 means better droplet uniformity for any spray pattern. Considering particle size distribution, relative span values were ranged from 1.201 to 1.575. The best relative span value was obtained for cone nozzle $(\mathrm{CN})$ type.

\section{Conclusions}

The following results can be drawn from this research;

In the spraying operations carried out with sitespecific method, the nearest results to the reference method (Broadcast) were obtained in air induction (AI) nozzle type with $60.5 \%$ deposition and $95.9 \%$ coverage rates.

The increase in travel speed adversely affected spray performance in both broadcast and sitespecific methods. Therefore, the lowest speed $(0.48$ $\mathrm{km} \mathrm{h}^{-1}$ ) was found to be the most successful.

Deposit amounts and coverage rates were decreased from the nozzle centre to the edges for both methods.

In all nozzle types used in the study; as a result of site-specific spraying applications, there was no deterioration in the pattern distribution.

\section{References}

Baran, M. F., Polat, R., \& Gökdoğan, O. (2016). Comparison of energy use efficiency of different tillage methods on the secondary crop sunflower production. Fresenius Environmental Bulletin, 25(11), 4937-4943.

Bolat, A. (2010). Çukurova bölgesinde misır yetiştiriciliğinde bazı ilaç uygulama yöntemlerinin etkinliklerinin saptanmasi. Doctoral thesis, Çukurova Üniversitesi Fen Bilimleri Enstitüsü Tarım Makinaları Anabilim Dalı Adana, Turkey.

Bolat, A., Bayat, A., Tetik, O., Karaagac, H. A., Cerit, I., \& Sevilmis, U. (2018). Performance of herbicide spraying methods at different application volumes in maize. Fresenius Environmental Bulletin, 27(5), 2963-2967.

Christensen, S., Søgaard, H. T., Kudsk, P., Nørremark, M., Lund, I., Nadimi, E. S., \& Jørgensen, R. (2009). Site specific weed control technologies. Weed Research, 49(3), 233-241. doi: 10.1111/j.13653180.2009.00696.x

Doruchowski, G., Świechowski, W., Masny, S., Maciesiak, A., Tartanus, M., Bryk, H., \& Hołownicki, R. (2017). Low-drift nozzles vs. standard nozzles for pesticide application in the biological efficacy trials of pesticides in apple pest and disease control. Science of the Total Environment, 575(5), 12391246. doi: 10.1016/j.scitotenv.2016.09.200

Loni, R., Loghavi, M., \& Jafari, A. (2014). Design, development and evaluation of targeted discreteflame weeding for inter-row weed control using machine vision. American Journal of Agricultural Science and Technology, 2(1), 17-30. doi: 10.7726/ ajast.2014.1003 
Martín, C. S., Andújar, D., Barroso, J., FernándezQuintanilla, C., \& Dorado, J. (2016). Weed decision threshold as a key factor for herbicide reductions in site-specific weed management. Weed Technology, 30(4), 888-897. doi: 10.1614/WT-D-16-00039.1

Özlüoymak, Ö. B., Bolat, A., Bayat, A., \& Güzel, E. (2019). Design, development, and evaluation of a target oriented weed control system using machine vision. Turkish Journal of Agriculture and Forestry, 43(2), 164-173. doi: 10.3906/tar-1803-8

Perez, A. J., Lopez, F., Benlloch, J. V., \& Christensen, S. (2000). Colour and shape analysis techniques for weed detection in cereal fields. Computers and Electronics in Agriculture, 25(3), 197-212. doi: 10.1016/S0168-1699(99)00068-X

Sabanc1, K., \& Aydın, C. (2014). Image processing based precision spraying robot. Tarim Bilimleri Dergisi, 20(4), 406-414. doi: 10.1501/Tarimbil_0000001299

Shirzadifar, A. M., Loghavi, M., \& Raoufat, M. H. (2015). Development and evaluation of a real time site-specific inter-row weed management system. Iran Agricultural Research, 32(2), 39-54.
Soysal, A., \& Bayat, A. (2006). Herbisit uygulamalarında kullanılan düşük sürüklenme potansiyelli memelerin püskürtme tekniği açısından değerlendirilmesi. Tarım Makinaları Bilimi Dergisi, 2(3), 189-195.

Tang, J. L., Chen, X. Q., Miao, R. H., \& Wang, D. (2016). Weed detection using image processing under different illumination for site-specific areas spraying. Computers and Electronics in Agriculture, 122(3), 103-111. doi: 10.1016/j.compag.2015.12.016

Tian, L., Reid, J. F., \& Hummel, J. W. (1999). Development of a precision sprayer for site-specific weed management. Transactions of the ASAE, 42(4), 893-901. doi: 10.13031/2013.13269

Yang, C. C., Prasher, S. O., Landry, J., \& Ramaswamy, H. S. (2002). Development of neural networks for weed recognition in corn fields. Transactions of the ASAE, 45(3), 859-866. doi: 10.13031/2013.8854 
